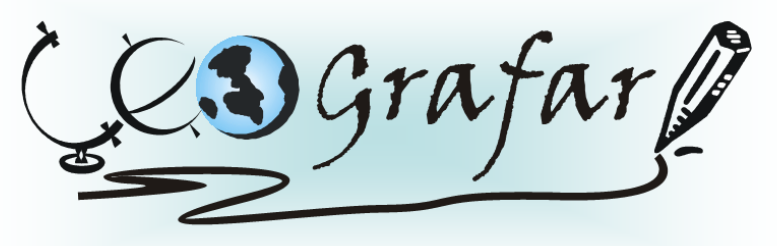

Revista Eletrônica do Programa de Pós-Graduação em Geografia - UFPR

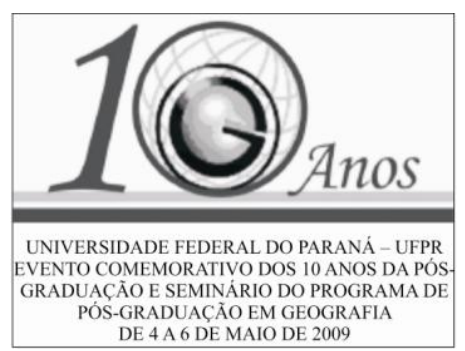

\title{
A NOVA TERRITORIALIDADE DAS ÁGUAS: LIMITES E DESAFIOS NA GESTÃO SOCIAL DAS BACIAS HIDROGRÁFICAS DO ESTADO DO PARANÁ.
}

\author{
PAULO CÉSAR MEDEIROS ${ }^{1}$ \\ NALDY EMERSON CANALI ${ }^{2}$
}

\section{LINHA DE PESQUISA: PAISAGEM E ANÁLISE AMBIENTAL}

No modelo de gestão de águas adotado no Estado do Paraná, o poder público, por meio de suas estruturas de gestão dos recursos hídricos, deve abrir de sua autonomia administrativa sobre a gestão de águas em território estadual para compartilhá-la com a nova instância deliberativa representada pelos Comitês de Bacia. Adicionalmente, a bacia hidrográfica, além de se apresentar como unidade de gestão ambiental, é também palco da gestão de conflitos relacionados aos aspectos quantitativos e qualitativos da água, que são base da gestão territorial. Ao lado dos chamados conflitos institucionais, interagem os conflitos sociais, decorrentes, por um lado, das diferentes pretensões setoriais quanto ao uso da água e, por outro, da compreensão da bacia hidrográfica como uma construção social, que pode fazer superar as práticas de gestão ambiental que levem ao desenvolvimento territorial sustentado. A partir da constituição dos instrumentos jurídicos e políticos estabelecidos na Política Estadual de Recursos Hídricos (1997), pode-se considerar que o modelo de gerenciamento estadual teve sua mudança de rumos e fez transparecer uma nova territorialidade das águas no espaço geográfico paranaense. Esta condição sócio-espacial da Bacia Hidrográfica que se apresentou nos tomou a atenção e sobre ela e gerou uma matriz de questões serem resolvidas no processo de pesquisa, sendo elas as seguintes: 1) Quais os conceitos geográficos necessários para a explicação deste modelo de gestão territorial adotado?, 2) Quais os conflitos sócio-ambientais gerados partir da implementação da Lei Estadual de Recursos Hídricos?, 3) Quais as territorialidades que emergem do processo de implementação desta lei?, 4) Quais as identidades territoriais dos setores envolvidos no processo de gestão hídrica?,

\footnotetext{
1 paulomedeiros@seed.pr.gov.br

2 Professor orientador
} 
5) Como se pode produzir uma nova identidade territorial levando em consideração as bacias hidrográficas? 6) Como se pode efetivar uma gestão social das águas que leve à superação das contradições econômicas e políticas do desenvolvimento socioambeintal?

Neste contexto, a pesquisa objetiva revelar as territorialidades que emergem do modelo de gestão integrada e compartilhada das Bacias Hidrográficas, em implementação no espaço geográfico paranaense a partir da Lei Estadual 12.726/99. A identificação das contradições e convergências contidas nos discursos e práticas setoriais, nos interesses políticos, econômicos e sociais presentes na luta interna do comitê, pode revelar a dimensão territorial da bacia hidrográfica. Na execução da pesquisa constam as seguintes etapas: 1) Entrevista com gestores e técnicos públicos para recolhimento documental, identificando as bases teóricas e técnicas que orientam a gestão de bacias hidrográficas; 2) Coleta de relatos da percepção dos setores envolvidos na gestão dos Comitês, identificando seus discursos e manifestações oficiais nas diferentes estruturas de participação; 3) Geração de banco de dados, instrumentos de coleta e matrizes avaliativas de resultados; 4) Representação dos dados estatísticos das condições ambientais das bacias hidrográfica estudadas, seus usos e cenários futuros, na perspectiva dos Planos de Bacia Hidrográfica. A pesquisa se justifica na necessidade concreta do conhecimento dos meios técnicos, jurídicos, políticos, institucionais, econômicos, ecológicos e ambientais que decorrem do modelo de gestão das águas adotado. Sustenta-se na hipótese de que a análise das territorialidades que emergem da gestão por bacia hidrográfica permite compreender as variáveis que se articulam para dar sentido a este espaço e pensar o desenvolvimento territorial nas diferentes escalas. Aponta que, a bacia hidrográfica instituída como unidade de gestão decisória no sistema de gerenciamento hídrico estadual, faz transparecer uma Geografia Política da Água, um campo de estudo estratégico para pensar a análise de bacias hidrográficas e a gestão social da água. Neste sentido, o presente ensaio resulta da percepção científica da necessidade que os pesquisadores, planejadores e gestores têm, de conhecer em profundidade os meios pelos quais decorrem e decorrerão os grandes enfrentamentos na gestão das águas e busca se justificar na possibilidade que a análise evolutiva da gestão do território oferece para a explicação das variáveis que se articulam para dar sentido às novas territorialidades em cada momento histórico.

PALAVRAS-CHAVE: Novas Territorialidades, Gestão Social das Águas, Comitês de Bacia Hidrográfica. 